\title{
Associations of Phoretic Mites on Bark Beetles of the Genus Ips in the Black Sea Mountains of Turkey
}

\author{
Cihan Cilbircioğlu ${ }^{1, *}$, Marta Kovač ${ }^{2}\left(\mathbb{D}\right.$ and Milan Pernek ${ }^{2}(\mathbb{D}$ \\ 1 Department of Organic Agriculture, Taşköprü Vocational School, Kastamonu University, \\ 37100 Kastamonu, Turkey \\ 2 Croatian Forest Research Institute, Division for Forest Protection and Game Management, Cvjetno naselje 41, \\ 10450 Jastrebarsko, Croatia; martam@sumins.hr (M.K.); milanp@sumins.hr (M.P.) \\ * Correspondence: cihancilbirci@hotmail.com
}

Citation: Cilbircioğlu, C.; Kovač, M.; Pernek, M. Associations of Phoretic Mites on Bark Beetles of the Genus Ips in the Black Sea Mountains of Turkey. Forests 2021, 12, 516. https:// doi.org/10.3390/f12050516

Academic Editor: Timothy A. Martin

Received: 14 January 2021

Accepted: 5 March 2021

Published: 22 April 2021

Publisher's Note: MDPI stays neutral with regard to jurisdictional claims in published maps and institutional affiliations.

Copyright: (c) 2021 by the authors. Licensee MDPI, Basel, Switzerland. This article is an open access article distributed under the terms and conditions of the Creative Commons Attribution (CC BY) license (https:// creativecommons.org/licenses/by/ $4.0 /)$.

\begin{abstract}
Phoretic mites use bark beetles for transportation to new, suitable habitats. Some phoretic mites act as predators and parasitoids of the bark beetles' immature stages, especially egg and early larval stages, and are potential agents for the biological control of scolytine forest pests. Mites live very frequently in relationships with other invertebrates. Many are found in association with various species of bark beetles. Here, a total of 41 specimens of different bark beetles of the genus Ips (Ips acuminatus, Ips sexdentatus and Ips typographus) were studied for presence, species composition, and abundance of phoretic mites. The beetles were collected on dead wood and parts of tree bark of Pinus nigra, Pinus sylvestris and Picea abies in the Black Sea Mountains in Kastamonu and Artin Province of Turkey. A total of nine mite species were found, including Dendrolaelaps quadrisetus, Ereynetes sp., Histiostoma piceae, Paraleius cf. leontonychus, Pleuronectocelaeno barbara., Proctolaelaps hystricoides, Schizostethus simulatrix, Trichouropoda lamellosa and Uroobovella ipidis. All species are identified for the first time within Turkish fauna.
\end{abstract}

Keywords: Acari; Ips sexdentatus; Ips acuminatus; Ips typographus; Pinus nigra; Pinus sylvestris; Picea abies; Turkey

\section{Introduction}

Bark beetles are known to be associated with diverse guilds of arthropods and microorganisms, of which phoretic mites are among the best-known. An important characteristic called "phoresy" defines this interspecific relationship where one species acts as a host and the other acts as a "phoront", attaching itself to the host in order to disperse or migrate [1] Phoretic mites use bark beetles for transportation to new suitable habitats and some species are able to impact bark beetle populations through parasitism or predation [2-5]. Recently, 270 mite species associated with different bark beetles have been identified [5,6], and up to now several new records have been registered and described [7]. Bark beetles are representatives of an ecologically, economically, and socio-politically important group that undergoes dramatic population eruptions, exerts high mortality to host plants at a landscape level, and fundamentally alters ecosystem structure and function under natural conditions [7-9]. For example, Ips typographus L. (Coleoptera, Curculionidae) is considered one of the most damaging pests in Eurasian Norway spruce (Picea abies (L.) Karst.) forests. Due to windthrows [10] or long-term drought [11] spruce bark beetle populations are able to increase to high numbers where the beetle can overcome the defences and kill vigorous trees [12]. Most coniferous forests are intensively managed to suppress outbreaks of bark beetles, although interventions could have limited effects on the population dynamics $[13,14]$. It has to be taken in account that tree-killing bark beetles were relatively few in number, but could have profound ecological effects [9]. However, the majority of bark beetles breeding in dead trees or tree parts and have the primary ecological role to initiate or contribute to the breakdown of wood by feeding, vectoring symbiotic microorganisms, 
or providing access for decay microorganisms [15]. These organisms contribute to nutrient cycling, soil structure, hydrology and so on, and are described as biological indicator of disturbances in the functioning of forest ecosystems. Bark beetles are important nutrient recyclers and consequently important components, and are likely beneficial to these ecosystems [16].

The role of associated organisms of bark beetles is insufficiently studied [3,5]. It is of particular practical importance that some phoretic mites act as predators and parasitoids of the bark beetles' immature stages, especially egg and early larval stages. They are thus potential biological control agents of scolytine forest pests [5,17]. Interaction with antagonistic fungi associated with bark beetles could affect bark beetle survival and reproduction $[18,19]$. Furthermore, mites facilitate the movement of microorganisms across trees [4].

Most mite species are predators, parasites, or symbionts of mammals, birds, reptiles, and arthropods [20]. Although it is well known that they live very frequently in relationships with other invertebrates [21] and have associations with various species of bark beetles [22], in many regions, like the Turkish Black Sea basin, there is a lack of knowledge about the species composition.

The Turkish Black Sea basin stretches from west to east along the southern part of the Black Sea. Rich flora with intact forests is characterized by the dominance of woody species such as Fagus orientalis Lipsky, Quercus spp., Carpinus betulus L., Pinus nigra Arn. [23]. Starting from the northeastern Black Sea coast (which is a part of tertiary Colchis refugia) towards the east, the climate gets drier, supporting a wealth of habitat varieties and vegetation types [24]. This landscape and habitat diversity is also reflected in soil animal communities which are also very high for any well-studied animal taxa [25]. Forests in the Artvin region are spread between two different zones: Eastern Black Sea Climate Zone and Eastern Anatolia Climate Zone. Local forests consist of essential tree species such as Picea orientalis, Fagus orientalis, Abies nordmanniana subsp. nordmanniana, Pinus sylvestris, Castanea sativa, Alnus glutinosa subsp. barbata, and Quercus spp. [26].

One of the insect groups that damages forests of the Turkish Black Sea basin is bark beetles, Scolytinae (Coleoptera: Curculionidae), together with many well-known species spectra [27-29]. The widely distributed European spruce bark beetle, I. typographus, is one of the most economically significant pests in the Palaearctic. Although it infests mainly spruce (Picea spp.), this beetle also occurs on other conifers, such as Pinus spp. and Abies spp. [30]. Ips sexdentatus Börner, Ips acuminatus Gyllenhal and Tomicus piniperda Linnaeus are the most damaging bark beetles in Turkey's forests, with I. sexdentatus causing serious economic losses in spruce (in particular P. orientalis). Previously, a strenuous effort has been expended to control this pest. Pheromone traps, and mechanical and chemical control strategies have been used for a long time, resulting in huge financial costs, and this pest still causes serious economic losses in oriental spruce forests in Turkey [31].

Little is known about the diversity and relationships between most mite taxa, so extensive sampling is required [5]. The purpose of this paper is to list new records of phoresy by mites on bark beetles. The aim of this study was to identify phoretic mites associated with bark beetles in Ilgaz Mountains of Northern Turkey, in order to make the first list of species composition in this region.

\section{Materials and Methods}

\subsection{Study Area and Sampling Procedures}

Fourteen sampling sessions were conducted in the Kastamonu region on dead wood of $P$. nigra in Kastamonu forests. The bark was on the beginning of rotting. On the other hand, 26 samples of tree bark of P. nigra, P. sylvestris and P. abies in Taşköprü, Küre, Daday, and Ilgaz forests were collected between April to June 2018 and 2019. Dead wood and parts of tree bark of P. nigra and P. sylvestris were collected at $1.5 \mathrm{~m}$ height from the forest floor. About $1 \mathrm{dm}^{2}$ of bark was usually removed and out of it 3-4 bark beetles were taken. In addition, several P. abies trunks were sampled from the forest of Artvin which is located 
in the Eastern Black Sea Region (Figure 1). The mite species were collected on I. sexdentatus and I. acuminatus in Kastamonu forests and on I. typographus in Artvin forests.

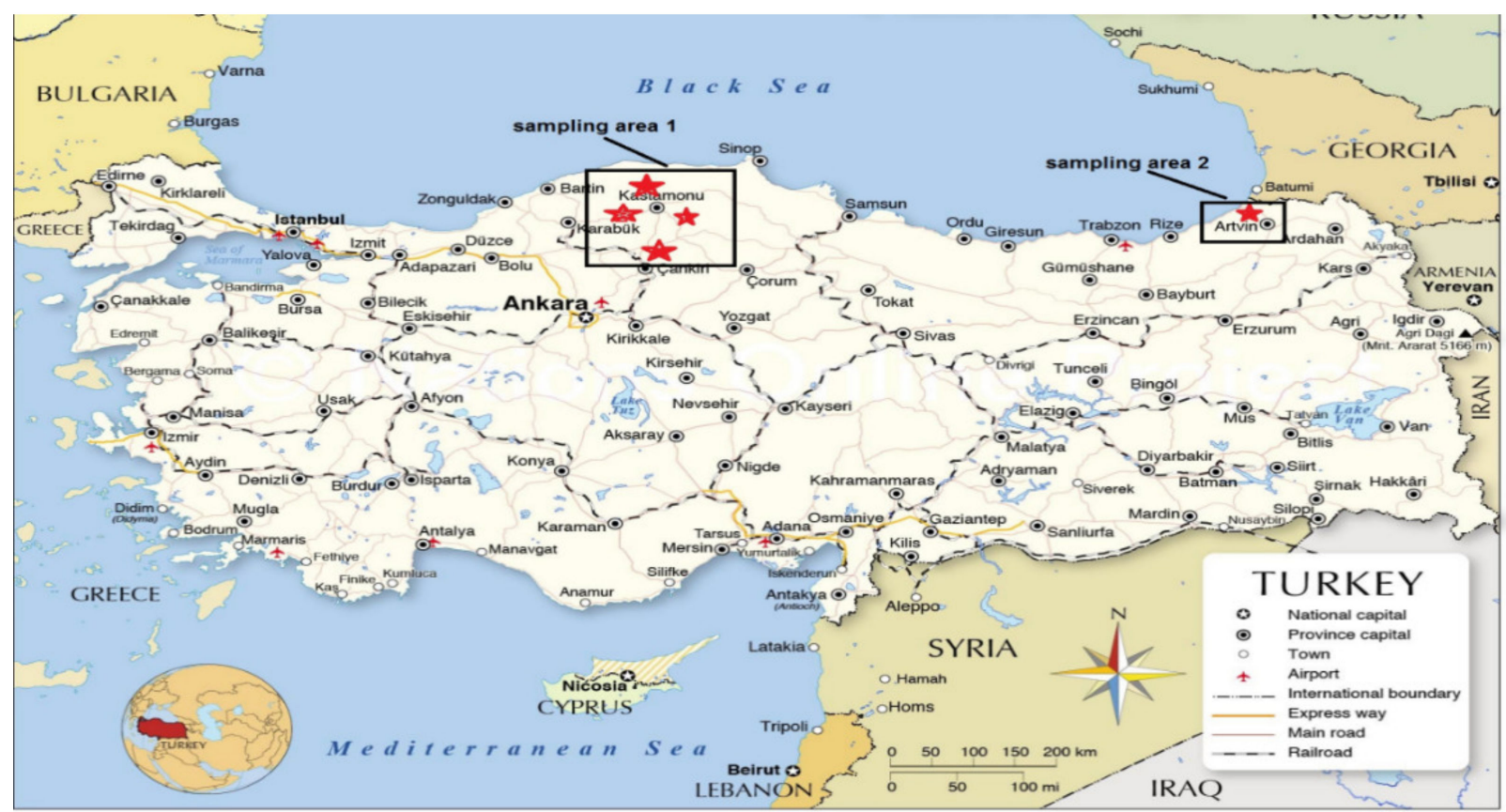

Figure 1. Map of the study area with the points of data collection.

\subsection{Sampling Procedures, Laboratory Treatment and Identification of Phoretic Mites}

All samples were placed in plastic bags, labelled, and transported to the laboratory in refrigerators. The collected bark beetles were placed into vials containing $96 \%$ ethanol. Mites were extracted using Berlese-Tullgren funnels for one week and individuals were stored in $80 \%$ ethyl alcohol. The phoretic mites specimens found on bark beetles were collected by C. Cilbircioglu and sent to M. Pernek (Laboratory for Entomological Analysis) for determination. The species were identified using comparative material from collection J.C. Moser and M. Pernek. Voucher specimens (slides) of all mite species detected in this study are stored in the collection of the main author.

\section{Results and Discussion}

The ecological roles of phoretic mites associated with bark beetles are generally poorly known. It is assumed that their biology and ecology are diverse $[3,9,11]$ and they can be beneficial or detrimental to beetles [1]. They may be filter feeders of bacteria and yeasts [32], prey on nematodes $[33,34]$, or they could prey on subcortical arthropods, even on small mites, eggs and immature stages of larger arthropods.

In total, 63 phoretic mites were extracted from 41 bark beetle adults in this study, belonging to eight families: Digamasellidae, Ereynetidae, Hemileiidae, Histiostomatidae, Melicharidae, Celaenopsidae, Uropodidae, and Urodinychidae. Nine species were recorded for the first time for the Turkish fauna (Table 1, Figure 2). 
Table 1. Abundance of phoretic mites on bark beetles (BB) Ips typographus, Ips sexdentatus and Ips acuminatus collected in Northern Turkey.

\begin{tabular}{|c|c|c|c|c|c|c|c|}
\hline $\begin{array}{l}\text { Mite Species, } \\
\text { Order, Family } \\
\quad \text { and } \\
\text { Phoretic Stage }\end{array}$ & $\begin{array}{l}\text { Location } \\
\text { on } \\
\text { Bark Beetle }\end{array}$ & $\begin{array}{c}\text { Total } \\
\text { Number of } \\
\text { Mites on BB }\end{array}$ & $\begin{array}{l}\text { Number of } \\
\text { Mites in } \\
\text { Alcohol } \\
\text { Sediments }\end{array}$ & $\begin{array}{l}\text { Number of } \\
\text { Mites in } \\
\text { Lactophe- } \\
\text { nol } \\
\text { Sediments }\end{array}$ & $\begin{array}{l}\text { Total } \\
\text { Number of } \\
\text { Mites }\end{array}$ & $\begin{array}{l}\text { Percent of } \\
\text { Total Mites } \\
\quad(n=63)\end{array}$ & $\begin{array}{l}\text { Additional Information on } \\
\text { Sites of Mite Species } \\
\text { Collection }\end{array}$ \\
\hline $\begin{array}{l}\text { Dendrolaelaps } \\
\text { quadrisetus } \\
\text { Mesostigmata, } \\
\text { Digamasellidae } \\
\text { Deutonymph }\end{array}$ & $\begin{array}{l}\text { Under elytra of } \\
\text { Ips sexdentatus } \\
\text { Ventral abdomen } \\
\text { of Ips acuminatus } \\
\text { Ventral thorax } \\
\text { and head of Ips } \\
\text { typographus }\end{array}$ & 10 & - & 1 & 11 & 17.5 & $\begin{array}{c}\text { Kastamonu Province: Taskköprü Disctrict, } \\
\text { Kapaklı Forests }\left(41^{\circ} 24 \text { N, } 34^{\circ} 19 \text { E), } 1203\right. \\
\text { m, on Pinus nigra L. } 22 \text { June 2019; } \\
\text { Daday District, Çamkonak Forests } \\
\left(41^{\circ} 23 \text { N, } 34^{\circ} 13 \text { E), } 1494 \text { m, on Pinus }\right. \\
\text { nigra L. } 30 \text { May 2018; } \\
\text { Küre District, Masruf Forests }\left(41^{\circ} 43 \text { N, }\right. \\
33^{\circ} 39 \text { E), } 1272 \text { m, on Pinus nigra L. } 30 \\
\text { May } 2018 ; \\
\text { Artvin Province }\left(41^{\circ} 11 \text { N, } 41^{\circ} 48 \text { E), } 708\right. \\
\text { m, on Picea abies L., } 24 \text { May } 2019\end{array}$ \\
\hline $\begin{array}{l}\text { Ereynetes sp. } \\
\text { Trombidiformes, } \\
\text { Ereynetidae } \\
\text { Female }\end{array}$ & $\begin{array}{l}\text { Leg of } \\
\text { Ips acuminatus }\end{array}$ & 1 & - & - & 1 & 1.6 & $\begin{array}{l}\text { Kastamonu Province: Küre District, } \\
\text { Masruf Forests }\left(41^{\circ} 43 \text { N, } 33^{\circ} 39 \text { E), } 1272\right. \\
\text { m, on Pinus sylvestris L. } 30 \text { May } 2018\end{array}$ \\
\hline $\begin{array}{l}\text { Histiostoma } \\
\text { piceae } \\
\text { Sarcoptiformes, } \\
\text { Histiostomatidae } \\
\text { Deutonymph }\end{array}$ & $\begin{array}{l}\text { Under elytra of } \\
\text { Ips sexdentatus }\end{array}$ & 1 & - & - & 1 & 1.6 & $\begin{array}{c}\text { Kastamonu Province: Ilgaz Mountains } \\
\left(41^{\circ} 22^{\prime} \mathrm{N}, 34^{\circ} 32^{\prime} \mathrm{E}\right), 1407 \mathrm{~m} \text {, on Pinus } \\
\text { sylvestris L., } 20 \text { April } 2018\end{array}$ \\
\hline $\begin{array}{l}\text { Paraleiuscf. } \\
\text { leontonychus } \\
\text { Sarcoptiformes, } \\
\text { Hemileiidae }\end{array}$ & Galleries of BB & - & 1 & - & 1 & 1.6 & $\begin{array}{l}\text { Kastamonu Province: Taşköprü District, } \\
\text { Kapaklı Forests }\left(41^{\circ} 25^{\prime} \text { N, } 34^{\circ} 18^{\prime} \text { E), } 917\right. \\
\text { m, on Pinus nigra L. } 21 \text { July } 2019\end{array}$ \\
\hline $\begin{array}{l}\text { Pleuronectocelaeno } \\
\text { barbara } \\
\text { Mesostigmata, } \\
\text { Neotenogyniidae } \\
\text { Female }\end{array}$ & $\begin{array}{l}\text { Under elytra of } \\
\text { Ips sexdentatus }\end{array}$ & 1 & - & - & 1 & 1.6 & $\begin{array}{l}\text { Kastamonu Province: Taşköprü District, } \\
\text { Kapaklı Village Forest Area }\left(41^{\circ} 24^{\prime} \mathrm{N},\right. \\
34^{\circ} 19^{\prime} \text { E), } 1312 \text { m, on Pinus nigra L., } 1 \\
\text { July } 2019\end{array}$ \\
\hline $\begin{array}{l}\text { Proctolaelaps } \\
\text { hystricoides } \\
\text { Mesostigmata, } \\
\text { Melicharidae } \\
\text { Female }\end{array}$ & $\begin{array}{l}\text { Ips acuminatus in } \\
\text { galleries of } \mathrm{BB}\end{array}$ & 20 & - & 2 & 22 & 34.9 & $\begin{array}{c}\text { Kastamonu Province: } \\
\text { Küre District, Masruf Forests }\left(41^{\circ} 43 \mathrm{~N},\right. \\
\left.33^{\circ} 39 \mathrm{E}\right), 1272 \mathrm{~m} \text {, on Pinus nigra L. } 30 \\
\text { May } 2018\end{array}$ \\
\hline $\begin{array}{l}\text { Schizostethus } \\
\text { simulatrix } \\
\text { Mesostigmata, } \\
\text { Melicharidae } \\
\text { Deutonymph }\end{array}$ & $\begin{array}{l}\text { Elytral declivity } \\
\text { of Ips typographus }\end{array}$ & 12 & - & - & 12 & 19.0 & $\begin{array}{l}\text { Artin Province }\left(41^{\circ} 11 \mathrm{~N}, 41^{\circ} 48 \mathrm{E}\right), 708 \mathrm{~m} \text {, } \\
\text { on Picea abies L. } 24 \text { May } 2019\end{array}$ \\
\hline $\begin{array}{l}\text { Trichouropoda } \\
\text { lamellosa } \\
\text { Mesostigmata, } \\
\text { Uropodidae } \\
\text { Deutonymph }\end{array}$ & $\begin{array}{l}\text { Elytral declivity } \\
\text { of Ips typographus } \\
\text { Dorsal thorax of } \\
\text { Ips sexdentatus }\end{array}$ & 10 & - & - & 10 & 15.9 & $\begin{array}{c}\text { Kastamonu Province: } \\
\text { Küre District, Masruf Forests }\left(41^{\circ} 43 \mathrm{~N},\right. \\
\left.33^{\circ} 39 \mathrm{E}\right), 1219 \mathrm{~m} \text {, on Pinus nigra L. } 17 \\
\text { July 2019; } \\
\text { Daday District, Çamkonak Forests } \\
\left(41^{\circ} 23 \text { N, } 33^{\circ} 13 \text { E), } 1494 \text { m, on Pinus }\right. \\
\text { nigra L. } 30 \text { May 2018; } \\
\text { Artin Province }\left(41^{\circ} 11 \text { N, } 41^{\circ} 48 \text { E), } 708 \text { m, }\right. \\
\text { on Picea abies L., } 24 \text { May } 2019\end{array}$ \\
\hline $\begin{array}{l}\text { Trichouropoda } \\
\text { lamellosa }\end{array}$ & Unknown & - & 1 & - & 1 & 1.6 & \\
\hline \multirow[t]{2}{*}{$\begin{array}{l}\text { Uroobovella } \\
\quad \text { ipidis } \\
\text { Mesostigmata, } \\
\text { Urodinychidae } \\
\text { Deutonymph }\end{array}$} & $\begin{array}{l}\text { Dorsal thorax of } \\
\text { Ips typographus }\end{array}$ & 3 & - & - & 3 & 4.7 & $\begin{array}{l}\text { Kastamonu Province: Küre District, } \\
\text { Masruf Forests }\left(41^{\circ} 43 \text { N, } 33^{\circ} 39 \text { E), } 1272\right. \\
\text { m, on Pinus nigra L., } 17 \text { July } 2019\end{array}$ \\
\hline & Total & 58 & 2 & 3 & 63 & 100.0 & \\
\hline
\end{tabular}


(a)
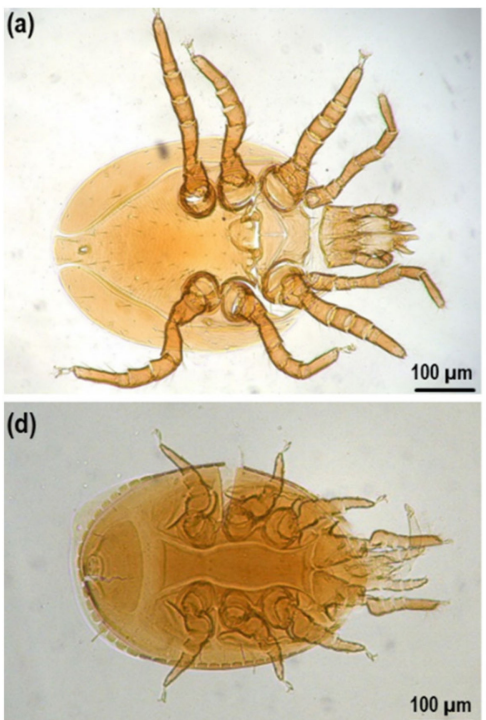

(g)

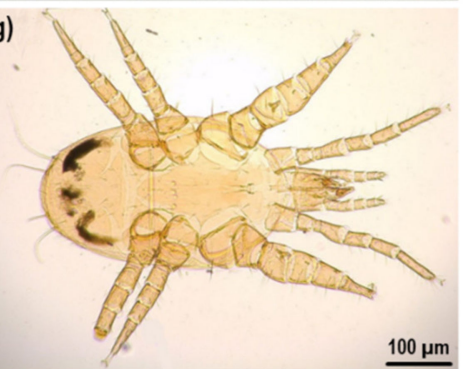

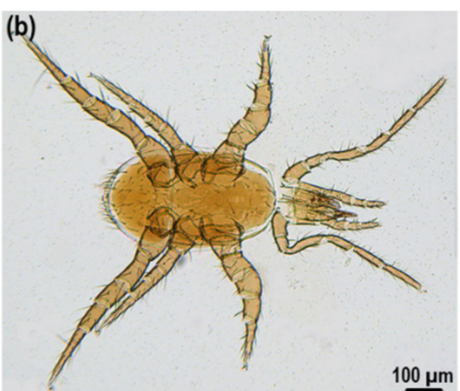

(e)
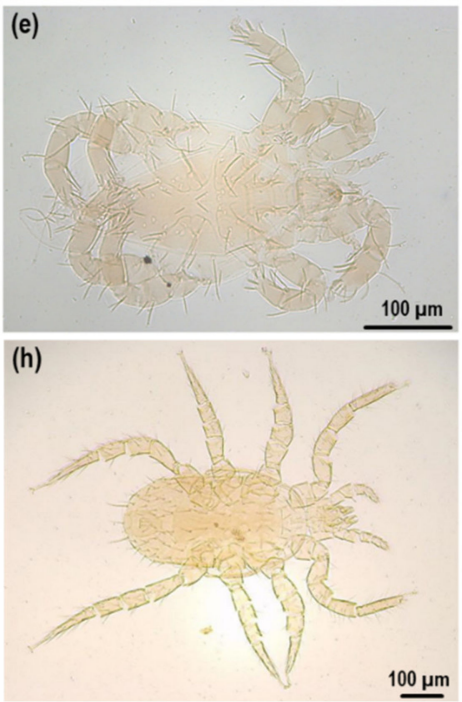

(c)

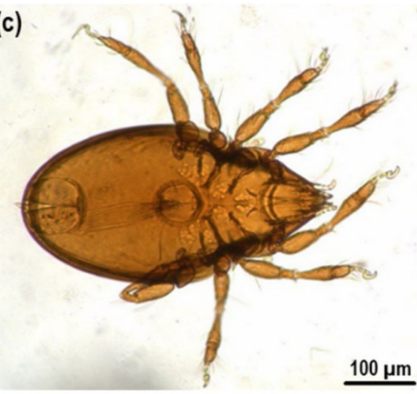

(f)
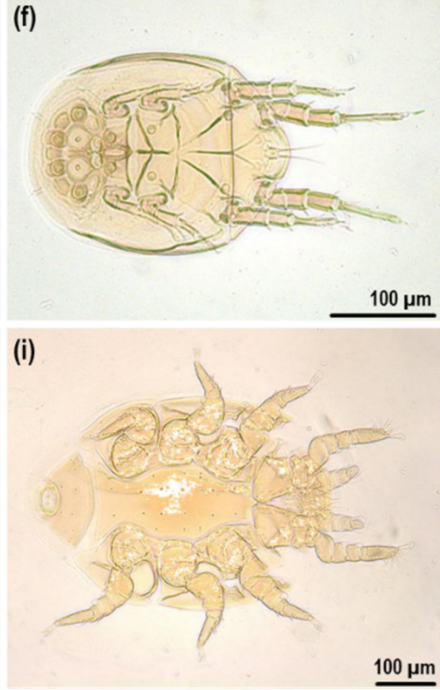

Figure 2. Phoretic mites from Ips spp. in Turkey (a) Pleuronectocelaeno barbara. (b) Schizostethus simulatrix. (c) Paraleius cf. leontonychus. (d) Trichouropoda lamellose. (e) Ereynetes sp. (f) Histiostoma piceae. (g) Dendrolaelaps quadrisetus. (h) Proctolaelaps hystricoides. (i) Uroobovella ipidis.

The mites were located under the elytra ( $8 \%$ ) and on the elytral declivity $(27 \%)$, dorsal thorax $(13 \%)$, ventral thorax $(5 \%)$, and legs $(7 \%)$. Of the five mites found in alcohol and lactophenol sediments, $92 \%$ were the same species as those attached to the beetles. A total of nine mite species were documented. All of these species were previously known to be phoretic: Dendrolaelaps quadrisetus (Berlese), Ereynetes sp., Histiostoma piceae (Scheucher), Paraleius cf. leontonychus, Pleuronectocelaeno barbara (Athias-Henriot), Proctolaelaps hystricoides (Lindquist and Hunter), Schizostethus simulatrix (Athias-Henriot), Trichouropoda lamellosa (Hirschmann) and Uroobovella ipidis (Vitzthum). Mites were either phoretic as females (Ereynetes sp., P. barbara, P. hystricoides) or as deutonymphs (D. quadrisetus, H. piceae, S. simulatrix, T. ipidis, T. lamellosa and U. ipidis) (Table 1).

The most abundant mite species in this study was Proctolaelaps hystricoides (34.9\%), which was rather rare in bark beetles from the Mediterranean region in previous studies [31] (Table 1). This species can feed on fungal spores [3], and in this study it was collected on galleries of I. acuminatus in P. nigra.

Also very abundant was Schizostethus simulatrix $(19.0 \%)$, collected on the elytral declivity of I. typographus in P. abies, and Dendrolaelaps quadrisetus (17.5\%) collected on all three bark beetle species (Table 1). S. simulatrix may prey on subcortical arthropods, as it is a member of the predatory mite family Parasitidae $[2,3]$.

Furthermore, Trichouropoda lamellosa was very abundant (15.9\%) collected on elytral declivity of I. typographus and dorsal thorax of I. sexdentatus in P. nigra and P. abies. This species usually preys on nematodes [32,33]. Uroobovella ipidis was relatively common (4.7\%), whereas Histiostoma piceae, Ereynetes sp. and Pleuronectocelaeno barbara were rare (Table 1). Most mite species were phoretic on I. sexdentatus (D. quadrisetus, H. piceae, P. barbara and T. lamellose). On I. typographus only two species were found (T. lamellose and U. ipidis), and 
two species (P. hystricoides and Ereynetes sp.) on I. acuminatus. In recent studies of phoretic mites on I. typographus in Romania, D. quadrisetus was the most abundant and frequent mite species, while less abundant was $H$. piceae [34]. Similar results were demonstrated in Spain on I. sexdentatus [35].

D. quadrisetus prey on nematodes and may have an important role in controlling bark beetle populations [32,33]. In Khaustov et al. [36] feeding on the eggs of I. typographus was observed. Specimens found in this research were collected under elytra of I. sexdentatus, on the ventral abdomen of I. acuminatus and ventral thorax, and head of I. typographus in P. nigra and P. abies. H. piceae was also collected under the elytra of I. sexdentatus in P. sylvestris, and like most members of this genus, this species may occur in liquid, "soupy" substrates, and may be a filter feeder of bacteria and yeasts [32].

No records exist about the feeding habits of $U$. ipidis. Here, this species was collected on the dorsal thorax of I. typographus in P. nigra.

Paraleius cf. leontonychus as a member of the oribatids is a detritivore species [37-39]. One specimen was collected from galleries of bark beetle I. acuminatus in P. nigra. Taking into consideration that there is more than one Paraleius phoretic mite species on European bark beetles [40] and by comparing the researched sample with species from the collection (Moser, Pernek), P. leontonychus could not be identified for sure so it was denoted as "cf".

Species of the genus Ereynetes sp. are small, soft-bodied prostigmatic predator mites that live on moss, lichens, litter, bat guano, in association with nests of scarabeids, birds, and mammals, in decomposing wood, in coleopteran galleries, and under bark [41-43]. Some species may feed on small mites, eggs, and immature stages of larger arthropods or on nematodes [41]. One specimen of this genus found in this research was collected from the leg of I. acuminatus in P. sylvestris. P. barbara was collected under elytra of I. sexdentatus in P. nigra. Some of these species may also feed on nematodes [44]. All phoretic mite species found and identified in this study are new records for the Turkish bark beetle phoretic fauna. Further field and laboratory research are required to precisely assess the feeding habits of the phoretic mites of Ips spp., and their potential use as biocontrol agents against bark beetles. Moreover, their role in transmitting of vascular wilt disease could be more important than presumed in terms of pine decline in Turkey, and also requires further investigation.

\section{Conclusions}

Some specific bark beetle species, mainly the genus Ips, damage conifer forests of the Turkish Black Sea basin. Control efforts for regulating the abundance are demanding, and in spite of numerous studies about bark beetle biology, there are still gaps in the knowledge of bark beetle outbreaks and the role of associated organisms. Here we present the species composition and abundance of phoretic mites of bark beetle species of the genus Ips in Turkey on three tree species. A total of nine mite species were recovered and all species are identified for the first time within Turkish bark beetle phoretic fauna. This first list and further research of phoretic mites on specific bark beetle and specific tree species, should build the base for ecological studies of the role of mites as associated organisms (e.g., their potential in biological control or possible role in transmitting of vascular wilt disease).

Author Contributions: C.C. and M.P. conceived and designed research; C.C. performed the field sampling; M.P. was responsible for the morphological identification; all authors equally contributed to the revision of the manuscript. All authors have read and agreed to the published version of the manuscript.

Funding: Kastamonu University (The Coordinator of Scientific Research Projects) in Turkey (Grant No: KÜ-BAP01/2018-26).

Institutional Review Board Statement: Not applicable.

Informed Consent Statement: Not applicable.

Data Availability Statement: MDPI Research Data Policies. 
Acknowledgments: This work was supported by Kastamonu University (The Coordinator of Scientific Research Projects) in Turkey (Grant No: KÜ-BAP01/2018-26).

Conflicts of Interest: The authors declare no conflict of interest.

\section{References}

1. Vissa, S.; Hofstetter, R.W. The role of mites in bark and ambrosia beetle-fungal interactions. Insect Physiol. Ecol. 2017, 135-156. [CrossRef]

2. Moser, J.C. Mite predators of the southern pine beetle. Ann. Entomol. Soc. Am. 1975, 68, 1113-1116. [CrossRef]

3. Pernek, M.; Hrasovec, B.; Matosevic, D.; Pilas, I.; Kirisits, T.; Moser, J.C. Phoretic mites of three bark beetles (Pityokteines spp.) on Silver fir. J. Pest. Sci. 2008, 81, 35-42. [CrossRef]

4. Hofsteter, R.W.; Moser, J.C. Role of mite sin insect-fungus associations. Ann. Rev. Entomol. 2014, 59, 537-557. [CrossRef]

5. Hofstetter, R.W.; Dikins-Bookwalter, J.; Davis, T.D.; Klepzig, K.D. Symbiotic associations of bark beetles. In Bark Beetles: Biology and Ecology of Native and Invasive Species; Vega, F.E., Hofstetter, R.W., Eds.; Elsevier/Academic Press: London, UK, 2015; pp. 209-245.

6. Hofstetter, R.W.; Moser, J.C.; Blomquist, S. Mites associated with bark beetles and their hypophoretic Ophiostomatoid fungi. In The Ophiostomatoid Fungi: Expanding Frontiers; Wingfield, S., Ed.; CBS-KNAW Fungal Biodiversity Centre: Utrecht, The Nederlands, 2013; pp. 165-176.

7. Kontschán, J.; Szőcs, G.; Kiss, B.; Khaustov, A.A. Bark beetle associated trematurid mites (Acari: Uropodina: Trematuridae) from Asian Russia with description of a new species. Syst. Appl. Acarol. 2019, 24, 1592-1603.

8. Schelhaas, M.J.; Nabuurg, G.J.; Schuck, A. Natural disturbances in the European forests in the 19th and 20th centuries. Glob. Chang. Biol. 2003, 9, 1620-1633. [CrossRef]

9. Raffa, K.F.; Aukema, B.H.; Bentz, B.J.; Carroll, A.L.; Hickl, J.A.; Turner, M.G.; Romme, W.H. Cross-scale drivers of natural disturbances prone to anthropogenic amplification: The dynamics of bark beetle eruptions. Bioscience 2008, 58, 501-517. [CrossRef]

10. Wermelinger, B. Ecology and management of the spruce bark beetle Ips typographus-A review of recent research. For. Ecol. Manag. 2004, 202, 67-82. [CrossRef]

11. Rouault, G.; Candau, J.N.; Lieutier, F.; Nageleisen, L.N.; Martin, J.C.; Warzée, N. Effects of drought and heat on forest insect populations in relation to the drought in western Europe. Ann. For. Sci. 2006, 63, 613-624. [CrossRef]

12. Mulock, P.; Christiansen, E. The threshold of successful attack by Ips typographus on Picea abies: A field experiment. For. Ecol. Manag. 1986, 14, 125-132. [CrossRef]

13. Burkhard, B.; Bässler, C.; Thorn, S.; Noss, R.; Schröder, B.; Dieffenbach-Fries, H.; Foullois, N.; Müller, J. Bark Beetles Increase Biodiversity While Maintaining Drinking Water Quality. Conserv. Lett. 2015, 8, 272-281.

14. Vanická, H.; Holuša, J.; Resnerová, K.; Ferenčík, J.; Potterf, M.; Vélea, A.; Grodzki, W. Interventions have limited effects on the population dynamics of Ips typographus and its natural enemies in the Western Carpathians (Central Europe). For. Ecol. Manag. 2020, 470-471, 118209. [CrossRef]

15. Lindgren, B.S.; Raffa, K.F. Evolution of tree killing in bark beetles (Coleoptera: Curculionidae): Trade-offs between the maddening crowds and a sticky situation. Can. Entomol. 2013, 145, 471-495. [CrossRef]

16. Cobb, T.P.; Hannam, K.D.; Kishchuk, B.E.; Langor, D.W.; Quideau, S.A.; Spence, J.R. Wood-feeding beetles and soil nutrient cycling in burned forests: Implications of post-fire salvage logging. Agric. For. Entomol. 2010, 12, 9-18. [CrossRef]

17. Pernek, M.; Wirth, S.; Blomquist, S.R.; Avtzis, D.N.; Moser, J.C. New associations of phoretic mites on Pityokteines curvidens (Coleoptera, Curculionidae, Scolytinae). Cent. Eur. J. Biol. 2012, 7, 63-68. [CrossRef]

18. Klepzig, K.D.; Moser, J.C.; Lombardero, F.J.; Hofstetter, R.W.; Ayres, M.P. Symbiosis and competition: Complex interactions among beetles, fungi and mites. Symbiosis 2001, 30, 83-96.

19. Lombardero, M.J.; Matthew, P.A.; Hofstetter, R.W.; Moser, J.C.; Klepzig, K.D. Strong indirect interactions of Tarsonemus mites (Acarina: Tarsonemidae) and Dendroctonus frontalis (Coleoptera: Scolytidae). Oikos 2003, 102, 243-252. [CrossRef]

20. Walter, D.E.; Lindquist, E.E.; Smith, I.M.; Cook, D.R.; Krantz, G.W. Order Trombidiformes. In A Manual of Acrology, 2nd ed.; Kranz, G.W., Lubbock, D.E., Eds.; Texas Tech University Press: Lubbock, TX, USA, 2009; pp. 83-94.

21. Rosario, R.M.T.; Hunter, P.E. The genus Myrmozercon Berlese, with descriptions of two new species (Acari: Mesostigmata: Laelapidae). J. Parasitol. 1988, 74, 466-470. [CrossRef]

22. Kiełczewski, B.; Moser, J.C.; Wiśniewski, J. Surveying the acarofauna associated with Polish Scolytidae. Bulletin de la société des amis des sciences et des lettres de Poznań. Ser. D Sci. Biol. 1983, 22, 151-159.

23. Zeydanli, U. Western Asia: Northern Turkey Extending along the Southern Black Sea Region. 2020. Available online: https: / / www.worldwildlife.org/ecoregions/pa0515 (accessed on 5 November 2020).

24. Williams, L.; Zazanashvili, N.; Sanadiradze, G.; Kandaurov, A. An Ecoregional Conservation Plan for Caucasus; WWF: Brussels, Belgium, 2006; p. 220.

25. Schütt, H. The Turkish Land Snails 1758-2005: Vollständig Revidierte und Erweiterte Auflage. Nat. Wiss. 2005, 1, 559.

26. Yüksek, T.; Ölmez, Z. A general assessment of climate, soil structure, forest areas, growing stock and some forestry applications of Artvin region. Artvin Çoruh Üniversitesi Orman Fakültesi Dergisi 2002, 3, 50-62.

27. Knížek, M. Platypodinae and Scolytinae. In Catalogue of Palaearctic Coleoptera; Löbl, I., Smetana, A., Curculionoidea, I., Eds.; Apollo Books: Stenstrup, Denmark, 2011; Volume 7, pp. 201-251. 
28. Sarikaya, O.; Avci, M. Predators of Scolytinae (Coleoptera: Curculionidae) species of the coniferous forests in the Western Mediterranean Region, Turkey. Turk. Entomoloji Derg. 2009, 33, 253-264.

29. Sarıkaya, O.; Knižek, M. Scolytus koenigi Schevyrew, 1890: A New Record for Turkish Scolytinae (Coleoptera: Curculionidae) Fauna. J. Entomol. Res. Soc. 2013, 15, 95-99.

30. Maslov, A.D. Koroed-Tipograf i Usykhanie Elovykh Lesov. Moscow Vserosiyskiy Nauchnoissledovatelskiy Inst. Lesovod. Mekhanizatsii Lesn. Khozyaystva 2010, 138, 320.

31. Yüksel, B.; Tozlu, G.; Şentürk, M. Sarıkamış Sarıçam (Pinus sylvestris L.) Ormanlarında Etkin Zarar Yapan Kabuk Böcekleri ve Bunlara Karşı Alınabilecek Önlemler. Doğu Akdeniz Ormancılık Araştırma Müdürlüğü. Tek. Bül. 2000, 1, 1-66.

32. O'Connor, B.M. Acarine-fungal relationships: The evolution of symbiotic associations. In Fungus-Insect Relationships: Perspectives in Ecology and Evolution; Wheeler, P., Blackwell, M., Eds.; Columbia University Press: New York, NY, USA, $1984 ;$ pp. 354-381.

33. Kinn, D.N. Notes on the life cycle and habits of Digamasellus quadrisetus (Mesostigmata: Digamasellidae). Ann. Entomol. Soc. Am. 1967, 60, 862-865. [CrossRef]

34. Paraschiv, M.; Isaia, G. Disparity of Phoresy in Mesostigmatid Mites upon their specific arrier Ips typographus (Coleoptera: Scolytinae). Insects 2020, 11, 771. [CrossRef]

35. Paraschiv, M.; Martinez-Ruiz, C.; Fernandez, M.M. Dynamic associations between Ips sexdentatus (Coleoptera: Scolytinae) and its phoretic mites in a Pinus pinaster forest in northwest Spain. Exp. Appl. Acarol. 2018, 75, 369-381. [CrossRef] [PubMed]

36. Khaustov, A.A.; Klimov, P.B.; Trach, V.A.; Bobylev, A.N.; Salavatulin, V.M.; Khaustov, V.A.; Tolstikov, A.V. Review of mites (Acari) associated with the European spruce bark beetle, Ips typographus (Coleoptera: Curculionidae: Scolytinae) in Asian Russia. Acarina 2018, 26, 3-79. [CrossRef]

37. Jacot, A.P. Acarina as possible vectors of the Dutch elm disease. J. Econ. Entomol. 1934, 27, 858-859. [CrossRef]

38. Walter, D.E.; Proctor, H.C. Mites: Ecology, Evolution, and Behaviour; CABI Publishing: New York, NY, USA, 1999.

39. Hunter, P.E. Five new mites of the subfamily Ereynetinae (Acarina: Ereynetidae). Fla. Entomol. 1964, 47, 181-193. [CrossRef]

40. Schaeffer, S.; Koblmueller, S. Unexpected diversity in the host-generalist oribatid mite Paraleius leontonychus (Oribatida, Scheloribatidae) phoretic on Palearctic bark beetles. PEERJ 2020, 8, e9710. [CrossRef] [PubMed]

41. Kinn, D.N. Incidence of pinewood nematode dauerlarvae and phoretic mites associated with long-horned beetles in central Louisiana. Can. J. For. Res. 1987, 17, 187-190. [CrossRef]

42. André, H.M.; Fain, A. Phylogeny, ontogeny and adaptive radiation in the superfamily Tydeoidea (Acari: Actinedida), with a reappraisal of morphological characters. Zool. J. Linn. Soc. 2000, 130, 405-448. [CrossRef]

43. O'Connor, B.; Klimov, P. Family Ereynetidae Oudemans. 2004. Available online: http://insects.ummz.lsa.umich.edu/beemites/ Species_Accounts /Ereynetidae.htm (accessed on 5 December 2020).

44. Kinn, D.N. The Life Cycle and Behavior of Cercoleipus coelonotus (Acarina: Mesostigmata), Including a Survey of Phoretic Mite Associates of California Scolytidae; University of California, Publications in Entomology: Berkeley, CA, USA, 1971; Volume 65, p. 66. 